\title{
Macrodactyly with skin hypertrophy: a minimal form of the Proteus Syndrome
}

Macrodactilia com hipertrofia da pele: uma forma mínima da síndrome de Proteu

\author{
Hiram Larangeira de Almeida $\mathrm{Jr}^{1}$ \\ Rudolf Happle ${ }^{3}$
}

\author{
Roberto Coswig Fiss ${ }^{2}$
}

\begin{abstract}
The Proteus syndrome was described 1983 . It has asymmetric gigantism of the limbs, verrucous epidermal naevi, cerebriform enlargement of the plantar region, vascular malformations and neoplasms, as lipomas. It received this denomination after Proteus from the Greek mythology, who had the ability to change his form . A 15 year-old boy, reported a congenital hypertrophy with syndactily of the second and third right fingers. The second case is a 35 year-old man, who reported that since birth the second right toe was bigger than the other toes, skin hypertrophy was also observed. These cases document a localized form if the Proteus syndrome, which may widen the spectrum of its variability.

Keywords: Hypertrophy; Hand deformities; Foot deformities

Resumo: A síndorme de Proteus foi descrita por Wiedemann em 1983. Ela é caracterizada por gigantismo assimétrico dos membros, nevos epidérmicos verrucosos, hipertrofia cerebriforme da região plantar, neoformações vasculares e neoplasias, como lipomas. Essa polimórfica enfermidade recebeu essa denominação segundo a figura da mitologia grega, a qual tinha como característica a habilidade de mudar de forma, para evitar sua captura. Examinou-se um menino de 15 anos, o qual referiu hipertrofia e sindactilia do segundo e terceiro quirodáctilos direitos e um homem de 35 anos, que referiu hipertrofia congênita do segundo pododáctilo direito. Havia hipertrofia da pele em ambos os casos. Esses dois pacientes documentam formas localizadas dessa síndrome, ampliando seu espectro clínico.

Palavras-chave: Deformidades congênitas do pé; Dermatoses da mão; Hipertrofia
\end{abstract}

\section{INTRODUCTION}

The Proteus syndrome was described by the German Pediatrician, Hans-Rudolf Wiedemann in $1983^{1}$. It is characterized by asymmetric gigantism of the limbs, verrucous epidermal naevi, cerebriform connective tissue nevus of the plantar region, vascular malformations and neoplasms, such as lipomas ${ }^{2-4}$. This peculiar syndrome received this denomination in comparison to Proteus from the Greek mythology, who was characterized by the ability to change his form to avoid capture.

We examined two cases of a localized form if the Proteus syndrome, which may widen the spectrum of its variability.

Recebido em 28.04.2010.

Aprovado pelo Conselho Consultivo e aceito para publicação em 01.06.2010.

* Study conducted at the Federal University of Pelotas (UFPel), at the Catholic University of Pelotas (UCPEL) and at the University of Marburg, Germany. Conflict of interest: None / Conflito de interesse: Nenbum

Financial funding: None / Suporte financeiro: Nenbum

Assistant Professor, Federal University of Pelotas, (UFPel). Adjunct Professor, Catholic University of Pelotas (UCPEL), Pelotas, Rio Grande do Sul, Brazil Currently participating in a Medical Residency Program at the Federal University of Health Sciences of Porto Alegre (UFCSPA), Porto Alegre, Rio Grande do Sul, Brazil.

Head of the Department of Dermatology, Emeritus Professor of the University of Marburg, Hesse, Germany.

(C)2011 by Anais Brasileiros de Dermatologia 


\section{CASE REPORTS}

The first case is a 15 year-old boy, who reported that since birth a hypertrophy with syndactily of the second and third right fingers was observed, the fingers were separated surgically. He asks for the possibility of a surgical treatment, since he feels some embarassement with his dysmorphic right hand. At skin examination an important macrodactily was seen (Figure 1) with some lateral deviation of the affected fingers. The hypertrophic nails were not dystrophic. The skin adjacent to the enlarged fingers was thicker than the rest of the back of the hand.

The second case is a 35 year-old man, who reported that since birth the second right toe was bigger than the other toes. The patient does not want to treat his condition. Skin examination showed hypertrophy of the second right toe (Figure 2), with adjacent enlargement of the plantar skin. The plantar dermatoglyphics were maintained in the hypertrophic skin area (Figure 2 ).

\section{DISCUSSION}

This multisystemic heterogeneous features were termed Proteus Syndrome, since it may be widely variable, as the Greek sea-god Proteus. The adjective derived from this name, protean, is used to denote mutant, variable, taking many forms.

The diagnosis may be established with manda-

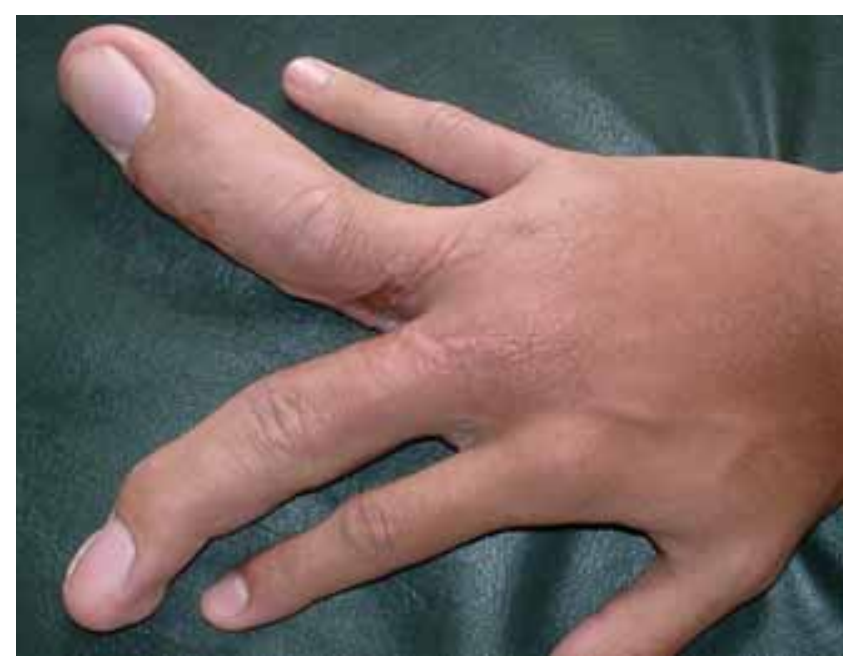

Figure 1: Hypertrophic third and fourth right fingers, with thickening of the skin on the back of the hand tory general criteria ${ }^{2}$ (mosaic distribution of lesions, progressive course and sporadic occurrence) and with specific criteria ${ }^{2}$, such as connective tissue nevus, or two of the following features (epidermal nevus, disproportionate growth of the limbs, skull hyperostosis, megalospondylodysplasia, visceromegaly, bilateral ovarian cystoadenomas or parotid adenoma), or three of the following criteria (dysregulated adipose tissue lipomas or fat absence, vascular malformations - capillary, venous or lymphatic, facial phenotype - dolichocephaly, long face, minor downslanting of palpebral comissures and/or minor ptosis, low nasal bridge, wide or anteverted nares, open mouth at rest) .

The cases here described have a localized distribution of lesions and are sporadic, with a skin hypertrophy, which may be considered a connective nevus and with localized limb overgrowth, the macrodactily, therefore they fulfill general and specific criteria to establish the diagnosis of Proteus syndrome.

There are many reports in the literature of macrodactily with skin hypertrophy, affecting fingers or toes ${ }^{5.9}$ some other cases were published as isolated macrodactily, probably before the description of the Proteus syndrome ${ }^{10-11}$.

This minimal acral variant should be included in the spectrum of the Proteus Syndrome and should be recognized by dermatologists.

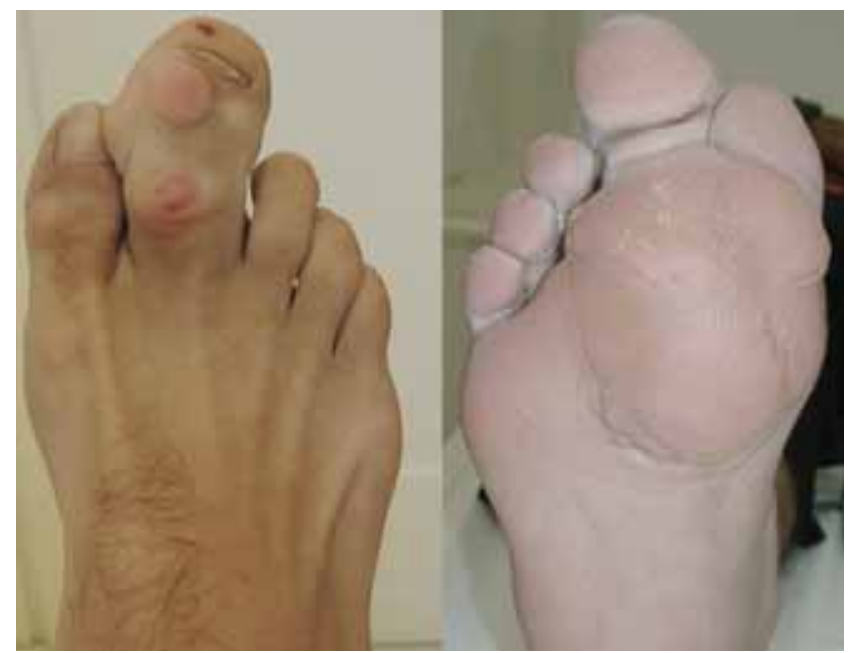

Figure 2: Hypertrophy of the second right toe. Partial enlargement of the ball of the foot. Note that the plantar dermatoglyphics are maintained in this area and also enlarged 


\section{REFERENCES}

1. Wiedemann HR, Burgio GR, Aldenhoff P, Kunze J, Kaufmann HJ, Schirg E. The proteus syndrome. Partial gigantism of the hands and/or feet, nevi, hemihypertrophy, subcutaneous tumors, macrocephaly or other skull anomalies and possible accelerated growth and visceral affections. Eur J Pediatr. 1983;140:5-12.

2. Biesecker LG, Happle R, Mulliken JB, Weksberg R, Graham Jr JM, Viljoen DL, et al. Proteus syndrome: diagnostic criteria, differential diagnosis, and patient evaluation. Am J Med Genet. 1999;84:389-95.

3. Cohen Jr MM. Proteus syndrome: an update. Am J Med Genet C Semin Med Genet. 2005;137:38-52.

4. Almeida HL Jr, Gonçalves NL . Importância das lesões cutâneas no diagnóstico da síndrome de Proteu. An Bras Dermatol. 1999;74:597-9.

5. Fraiture AL, Ihou ED, Piérard GE. Proteus syndrome of the hand. Dermatology. 2002;204:318-20

6. Morelli F, Feliciani C, Toto P, De Benedetto A, Tulli A. A minimal form of Proteus syndrome presenting with macrodactyly and hand hyperplasia. Eur J Dermatol. 2003;13:196-8.

7. Lacombe D, Battini J. Isolated macrodactyly and Proteus syndrome. Clin Dysmorphol. 1996;5:255-7.
8. Guelfi M, Camera A, Picchetta F, Pozzolo S, Camera G. Isolated macrodactyly or extremely circumscribed Proteus syndrome? Pathologica. 1994;86:681-4.

9. van Bever $\mathrm{Y}$, Hennekam RC. Isolated macrodactyly or extremely localized Proteus syndrome? Clin Dysmorphol. 1994;3:351-2.

10. Nitidandhaprabhas P. Congenital megalodactyly. Arch Dermatol. 1976;112:1036.

11. Barsky AJ. Macrodactyly. J Bone Joint Surg. 1967;49:1255-66.

MAILING ADDRESS / ENDEREÇO PARA CORRESPONDÊNCIA:

Dr. Hiram Larangeira de Almeida Jr.

Mestrado em Saúde e Comportamento - UCPEL

Rua Barroso 1202 - 107

96010-280 Pelotas RS, Brazil

E-mail: hiramalmeidajr@botmail.com

How to cite this article/Como citar este artigo: Almeida Jr H, Fiss RC, Happle R. Macrodactily with skin hypertrophy: a minimal form of the Proteus Syndrome. An Bras Dermatol. 2011;86(3):557-9. 